\title{
Birds of Algonquin Park
}

By Ron Tozer. 2012. The Friends of Algonquin Park, Whitney, Ontario. 474 pages. 49.95 CAD.

Algonquin Provincial Park, the oldest park in Ontar io, has long been a "must visit" destination for domestic and international tourists, and more recently for the ever-growing coterie of birders. This long awaited book will appeal to both groups. It supersedes the only previous attempt at cataloguing the Park's avifauna, the badly outdated "Birds of Algonquin Provincial Park" (1938) by Duncan MacLulich. Given the author's 40year history as Park Naturalist at Algonquin and his fame as one of Ontario's most respected birders, it is no surprise that he has produced a work that will stand as a shining example of regional bird inventories, a genre that is growing in popularity, other examples of which include those for the Hamilton region, the Niagara region, Presqu'ile Provincial Park, and Tozer's own co-authored book on the Oshawa-Lake Scugog region. Like some of those others, this book does much more than simply listing the birds that have been recorded in the Park. It devotes a few pages to describing the Park and to guiding visitors, both the casual persons with a passing interest in its wildlife and those who wish to go there specifically for birding and who know that there are certain northern specialties for which Algonquin Park is noted. The author offers general bird-finding advice to the former (including a surprising suggestion to use tape recordings to solicit responses from Barred Owls and Spruce Grouse) and more specific instructions for the more devoted birders, with insights that no one else could provide. Forty high quality photographs of typical Algonquin bird species make the book even more attractive to both groups.

The core of the book, more than 300 pages, is devoted to describing the status of the 278 bird species (and a few subspecies) that have been recorded in the Park. Each species account begins with a brief outline of what a non-birding visitor might want to know about the bird, and in many cases a small black-and-white sketch. Frequent sidebars are very informative, especially concerning bird behaviour. For the more serious birders, there is detailed season-by-season information on records dating back fifty years and less detailed information dating back over one hundred years. In the latter case, Tozer relies on records sup- plied by early naturalists such as, among others, Hoyes Lloyd (former president of the American Ornithologists' Union), Mark Robinson (the first Park Ranger in Algonquin), and his daughter Ottelyn Addison (whose grandson tells me she was "an incredible naturalist"). The bird data include average and extreme arrival and departure dates for migrants as well as whatever is available on their breeding status and on population trends. For some guilds, notably the shorebirds, it is necessarily an arbitrary decision as to what constitutes an extremely late spring departure date as opposed to an early fall arrival date. In the same vein, differentiating between molt migrant Canada Geese and earlier migrants, or between the subspecies of Canada Geese is also necessarily arbitrary. In some cases, the author uses the term "apparent migrants" to indicate that there is no easy way of knowing whether, for example, a bird seen in late fall or late winter is on the one hand an unusually late fall migrant or an early spring migrant or on the other hand a bird that is over-wintering in the Park.

With such an extensive data base available, Tozer has taken the innovative step of separating migration records of the most recent quarter century from those of the preceding one, where the sample sizes allow that, so as to highlight phenological trends. What that reveals is worrisome in many cases, though it is not clear whether changes may be attributed to climate change, as suggested in many of the species accounts, or to the greatly increased number of competent birders who have contributed their sightings to the Park's records. At the very least, those records can be mined by a researcher willing to go beyond simply determining whether the changes are statistically significant, which Tozer has done in collaboration with his son, Doug. Even the simple step of counting the number of species that are arriving earlier in the spring or departing later in the fall and comparing that with the number not showing such a trend could be potentially revealing. A more useful step would discriminate between what Tozer calls "short-distance migrants" and neo-tropical migrants to see whether the trends differ between the two groups. If nothing else, the 
details that are provided for all extremely early or late migrants, including locations of the sightings and the names of the observers, should appeal to those birders (and there are many) who are obsessed with delving into records. Bar graphs for each species neatly summarize what is in the text.

That subset of the birding community, often identified as "listers," will puzzle over the absence of certain species from the exhaustive record of sightings in Algonquin Park. One of the most surprising omissions from the cumulative list is Barrow's Goldeneye, given that Algonquin Park is not far from other places where it is relatively common, such as the Ottawa River. Birders who regularly frequent Presqu'ile Provincial Park are in the habit of sharing their predictions for the next new species to be added to that Park's bird list. In the case of Algonquin Park, this reviewer would put his money on Barrow's Goldeneye as the next new species to be added to the Park list, but would offer as other likely candidates Gyrfalcon, Parasitic Jaeger, Willow Flycatcher, Cerulean Warbler, and Willow Ptarmigan. These omissions, clearly not the fault of any observer, least of all the authors of this book, should not detract from the fact that Algonquin Park has welcomed a truly remarkable variety of vagrants, sufficient to make listers reading the book salivate. Coloured photographs taken at the time of observation showing fourteen of those rarities are a further feature of the book. One can only speculate on the reason(s) why so many tantalizing oddities have appeared in the Park. Perhaps the extensive forest comprising most of the Park makes the few clearings and roads serve as oases for species with a different habitat preference. Adding to the appeal of the book is the inclusion of fascinating anecdotes about the circumstances surrounding the discovery of some of the rare species. Those hundreds of birders who have participated in the Algonquin Park Christmas Bird Counts, as well as many who have not had that pleasure, will delight in seeing the table that shows the results of those 38 counts, as shown in an appendix.

A reviewer of any book, no matter how enthusiastic about it (as this reviewer is), has an obligation to point out its weaknesses. Most of the ones in this book are of a technical nature that do not affect the content of the book. Eight scientific species names are misspelled (all but one in the bibliography), as are eight individuals' names, a couple of place names, and a remarkably small number of other words. I have not checked all of the references, but at least two of them (Saunders 1947, /Flashing Wings/, page 200 - cited in a footnote to the Olive-sided Flycatcher account; and Weir 2009 - cited in the Green Heron account) are missing from the bibliography, the compiling of which in itself nevertheless represents a prodigious effort on the part of the author. Sixteen items are alphabetically misplaced in the various appendices. There are also numerous instances in which the text of a species account does not correspond with the information presented in tabular form immediately below the text. These and other trivial flaws do not detract from an otherwise excellent book, but should be remedied in any future edition.

Ron Tozer's "Birds of Algonquin Park " is certain to find a place of honour on the bookshelf of every serious birder in Ontario and may well become a best seller in the bookstore of the Friends of Algonquin Park. It will also serve as a reference book for many years, even as new information on the bird life of the Park continues to accrue.

Fred Helleiner

186 Bayshore Road, Brighton, Ontario K0K 1H0 Canada 